\title{
Article \\ Coumarin Interferes with Polar Auxin Transport Altering Microtubule Cortical Array Organization in Arabidopsis thaliana (L.) Heynh. Root Apical Meristem
}

\author{
Leonardo Bruno ${ }^{1, *}$, Emanuela Talarico ${ }^{1}$, Luz Cabeiras-Freijanes ${ }^{2,3}$, Maria Letizia Madeo ${ }^{1}$, Antonella Muto ${ }^{1}$, \\ Marco Minervino ${ }^{1}$, Luigi Lucini ${ }^{4}\left(\mathbb{D}\right.$, Begoña Miras-Moreno ${ }^{4}$, Adriano Sofo ${ }^{5}$ and Fabrizio Araniti ${ }^{6, *}$ (D)
}

Citation: Bruno, L.; Talarico, E.; Cabeiras-Freijanes, L.; Madeo, M.L.; Muto, A.; Minervino, M.; Lucini, L.; Miras-Moreno, B.; Sofo, A.; Araniti, F. Coumarin Interferes with Polar Auxin Transport Altering Microtubule Cortical Array Organization in Arabidopsis thaliana (L.) Heynh. Root Apical Meristem. Int. J. Mol. Sci. 2021, 22, 7305 https://doi.org/10.3390/ijms22147305

Academic Editor: Toshio Morikawa

Received: 13 June 2021

Accepted: 5 July 2021

Published: 7 July 2021

Publisher's Note: MDPI stays neutra with regard to jurisdictional claims in published maps and institutional affiliations.

Copyright: (c) 2021 by the authors. Licensee MDPI, Basel, Switzerland. This article is an open access article distributed under the terms and conditions of the Creative Commons Attribution (CC BY) license (https:// creativecommons.org/licenses/by/ $4.0 /)$.
1 Dipartimento di Biologia, Ecologia e Scienza della Terra, Università della Calabria (DiBEST-UNICAL), 87036 Arcavacata di Rende, Italy; emanuela.talarico@unical.it (E.T.); marialetizia.madeo@unical.it (M.L.M.); antonella.muto@unical.it (A.M.); marco.minervino@unical.it (M.M.)

2 Department of Plant Biology and Soil Science, Campus Lagoas-Marcosende, University of Vigo, 36310 Vigo, Spain; lcabeiras@uvigo.es

3 CITACA, Agri-Food Research and Transfer Cluster, Campus da Auga, University of Vigo, 32004 Ourense, Spain

4 Department for Sustainable Food Process, Università Cattolica del Sacro Cuore, Via Emilia Parmense 84, 29122 Piacenza, Italy; luigi.lucini@unicatt.it (L.L.); mariabegona.mirasmoreno@unicatt.it (B.M.-M.)

5 Department of European and Mediterranean Cultures: Architecture, Environment, and Cultural Heritage (DICEM), University of Basilicata, 75100 Matera, Italy; adriano.sofo@unibas.it

6 Dipartimento di Scienze Agrarie e Ambientali-Produzione, Territorio, Agroenergia, Università Statale di Milano, Via Celoria n², 20133 Milano, Italy

* Correspondence: leonardo.bruno@unical.it (L.B.); fabrizio.araniti@unimi.it (F.A.)

Abstract: Coumarin is a phytotoxic natural compound able to affect plant growth and development. Previous studies have demonstrated that this molecule at low concentrations $(100 \mu \mathrm{M})$ can reduce primary root growth and stimulate lateral root formation, suggesting an auxin-like activity. In the present study, we evaluated coumarin's effects (used at lateral root-stimulating concentrations) on the root apical meristem and polar auxin transport to identify its potential mode of action through a confocal microscopy approach. To achieve this goal, we used several Arabidopsis thaliana GFP transgenic lines (for polar auxin transport evaluation), immunolabeling techniques (for imaging cortical microtubules), and GC-MS analysis (for auxin quantification). The results highlighted that coumarin induced cyclin B accumulation, which altered the microtubule cortical array organization and, consequently, the root apical meristem architecture. Such alterations reduced the basipetal transport of auxin to the apical root apical meristem, inducing its accumulation in the maturation zone and stimulating lateral root formation.

Keywords: specialized metabolite; phytotoxic; lateral roots; root apical meristem; root swelling; cortical microtubules

\section{Introduction}

Because of sessile conditions, plants have evolved marked metabolic plasticity to increase their defense and competitive abilities. They have developed different biochemical pathways involved in the biosynthesis of a plethora of specialized metabolites to counteract the challenges arising during their growth and development [1]. These small molecules, characterized by an overwhelming structural diversity, a robust taxonomic restriction, and specificity within species, play a pivotal role in plant survival and adaptation to the environment. Plants could use them for a wide range of functions such as communication, reproductive purposes, nutrient acquisition, and trophic interactions [2,3]. For most known secondary metabolites, their specific ecological role, their involvement in physiological processes, and their mode of action have not yet been established [4]. 
The plant-plant interaction mediated by specialized metabolites is known as allelobiosis (positive interaction) and allelopathy (negative interaction), and the molecules at the basis of these interactions are known as allelochemicals. This ecological phenomenon plays an essential role in plant adaptation and competitive ability in the ecosystem, allowing plants to positively or negatively affect neighbouring species' growth and development [5].

Some allelochemicals used by plants as a chemical weapon to increase their competitive abilities could represent promising alternatives for producing new potential ecofriendly herbicides [6]. Moreover, they could positively/negatively affect the growth and development of sensitive species interfering with several biochemical and physiological aspects shaping their morphology [7].

Coumarins constitute a widely studied class of allelochemicals produced through the phenylpropanoid pathway via o-hydroxycinnamic acid lactonization $[8,9]$. They are present in almost all higher plants and microorganisms and are actively released into the environment through root exudation or dead plant tissue decay [10,11]. These specialized metabolites are involved in several ecological roles, such as the modulation of dynamical processes of species coexistence in plant communities [12], Fe acquisition and assimilation through root hair exudation and re-absorption [13-16], and the shaping of root microbiome composition [17].

The simplest compound belonging to this chemical class is 1,2-benzopyrone, also known as coumarin, mostly known for its phytotoxicity and potential hormone-like activity $[18,19]$. One of the first hypotheses suggesting an auxin-like effect of coumarin was proposed by Neumann [20]. He demonstrated that this specialized metabolite stimulated the elongation of Helianthus hypocotyls' excised segments, suggesting that its action was comparable to auxin. This hypothesis was further supported by Jansson and Svensson [21], who observed that coumarin alone causes an increase in fresh weight mainly by stimulating large numbers of roots and increasing soybean biomass. Abenavoli et al. [19], studying the effects of coumarin on the root morphology of Arabidopsis thaliana, observed that low concentrations $(\simeq 100 \mu \mathrm{M})$ of this molecule reduced primary root growth and stimulated the lateral root number parameter. Those findings strongly supported the hypothesis that coumarin could exert an auxin-like activity or interact with auxin distribution within the root. Successively, Lupini et al. [22], using several transgenic lines of Arabidopsis thaliana (defective in influx and efflux carriers), demonstrated that the efflux carrier PIN2 and the influx carrier AUX1 could be involved in coumarin-induced root branching, suggesting that auxin redistribution might be directly or indirectly affected by this molecule.

However, the exact mechanism of coumarin on root growth has not been clarified yet. A complex molecular signalling network probably governs coumarin's morphophysiological responses, where auxin transport and/or biosynthesis could play an important role. In fact, auxin is considered the leading candidate in controlling the stress-induced morphogenic response inducing the inhibition of root elongation, enhancing lateral roots formation and stimulating the production of adventitious roots under stressful environmental conditions $[23,24]$. Its polar transport plays a central role in organ development and elongation, in shoot/root branching and plastic growth responses [25], in lateral root initiation [26,27], in lateral root primordial formation [28], and in emergence [29]. Transported via influx and efflux proteins in a polarized stream, auxin action depends on its differential distribution along with tissues [28,30], and it is known that its fluxes are driven by an interplay between cell wall structure and the dynamics of microtubule and actin filaments [31]. Moreover, it has been demonstrated that intact microtubules are required for polar auxin trafficking [32].

Recently, it has been demonstrated that several natural compounds exert their biological activity interfering with auxin distribution along the root and its biosynthesis [33-40]. Moreover, it has been proven that compounds such as citral, farnesene, norharmane, weisiensin $\mathrm{B}$, and narciclasine strongly affect the microtubule organization, altering the root ultrastructure of the Arabidosis root, as well as its isotropic growth [33,36,37,41,42]. As two of the main effects exerted by coumarin are lateral roots formation and root tip 
swelling (a phenomenon observed with several microtubule interferents) [43], and the maintenance of auxin fluxes is known to depend on the interaction between cytoskeleton and PINs proteins [31], we hypothesized that the main coumarin effects could be related to microtubule alteration, followed by an alteration in PIN distribution. Therefore, using sub-lethal doses of coumarin, we decided to investigate coumarin's effects on the primary root tip anatomy, microtubule organization, and polar auxin transport, trying to deepen our knowledge on the potential mode of action of this specialized metabolite.

\section{Results}

\subsection{Effects of Coumarin on RAM}

Seven days of coumarin treatment significantly altered the RAM of Arabidosis (Figures 1 and 2). In particular, coumarin-treated roots were characterized by a reduction in MCN (46\% lower than that in control) (Figure 2a), accompanied by a decrease in MZL (44\%) (Figure 2b) and an increase in MZW (1.2-fold higher than that in control) (Figure 2c). In coumarin-treated seedlings, these data suggest the advancement of the transition zone and a premature exit of cells from the meristematic area (Figures 1 and 2).

The advancement of the transition zone in coumarin-treated roots was accompanied by an abnormal shape and asymmetric organization of protodermis and precortex cells characterized by a swollen and abnormal shape (Figure 1a-d). Therefore, we decided to quantify these alterations by measuring protodermis, precortex, proendodermis, and procambium cells at the first elongated precortex cell level.

In coumarin-treated seedlings, the protodermis, precortex, and proendodermis cells ${ }^{\prime}$ length and width were significantly increased by the treatment (Figures 1 and 2d,e). On the contrary, the length $(34 \%)$ and width $(16 \%)$ of procambium cells were significantly reduced and increased, respectively (Figure $2 \mathrm{~d}, \mathrm{e}$ ). On the contrary, the number of cell files forming the procambium was significantly higher $(40 \%)$ than that in control (Figure $2 \mathrm{~h}$ ). Besides, a substantial alteration at the columella level was also observed. The columella of the Arabidosis-treated roots was characterized, compared to the control, by a reduction in CL $(28 \%)$ and an increase in CW (18\%) (Figure 2f). In addition, the number of statoliths was significantly reduced by the treatment (60\% lower than that of the control) (Figure 2g), but no changes in columella stem cell layers were observed (data not shown). Other significant alterations in treated roots, such as incomplete cell division, fused lateral roots, high production of root hairs close to the meristem, and a high production of adventitious root primordia, were observed (Figure S1a-d).

Concerning cortical microtubule immunolabeling, in control roots, microtubules were well-defined and typically arranged, parallel to the transverse axis of the cells, and uniform in density (Figure $3 \mathrm{a}, \mathrm{c}$ ). On the contrary, in treated roots, they were erratically arranged with evident loss of symmetry, reduced density, and microtubule strands thicker than those of the control (Figure 3b,d).

Finally, the alterations observed on colchicine-treated roots are similar to those of seedlings treated with coumarin, confirming its potential effect as a microtubule effector (Figure S2). 


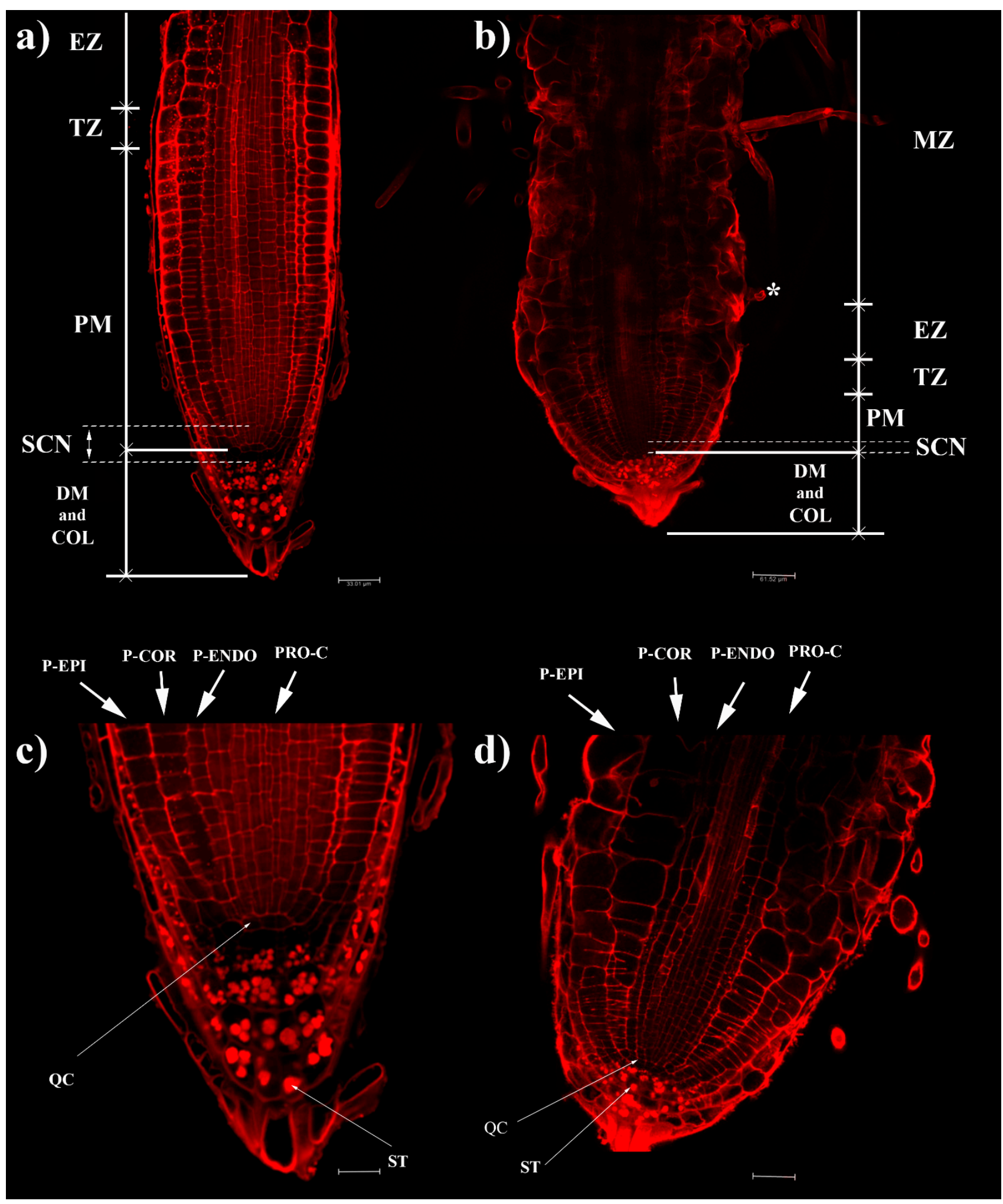

Figure 1. (a-d) Confocal laser microscope images of primary root tip, stained with propidium iodide, in 4 days old seedlings of $A$. thaliana treated for 7 days with coumarin $0(\mathbf{a}, \mathbf{c})$ and $100 \mu \mathrm{M}(\mathbf{b}, \mathbf{d})$. (c,d) Higher magnification of $(\mathbf{a}, \mathbf{b})$, respectively. Arabidosis RAM developmental zones: meristematic zone (MZ), the transition zone (TZ), and the elongation zone (EZ). The meristematic zone is divided into the distal meristem (DM) and the proximal meristem (PM). Moreover, in RAM, the stem cell niche (SCN) could be observed, as well as the quiescent center (QC), statoliths (ST), protodermis (P-EPI), precortex (P-COR), proendodermis (P-ENDO), and procambium (PRO-C); * first visible root hair. Scale bars: (a) 33.01; (b) 61.52; (c) $66.02 ;$ (d) $123.04 \mu \mathrm{m} . \mathrm{N}=20$. 
a) 35

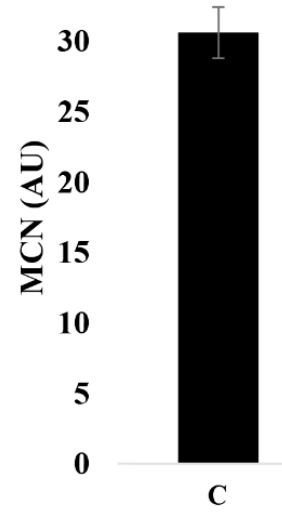

b) 300

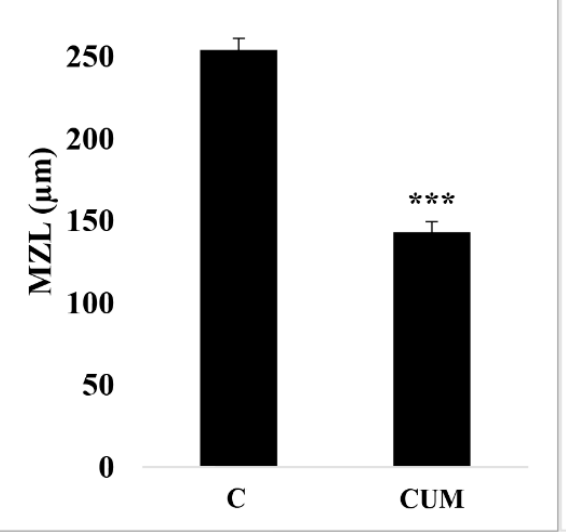

c) 180

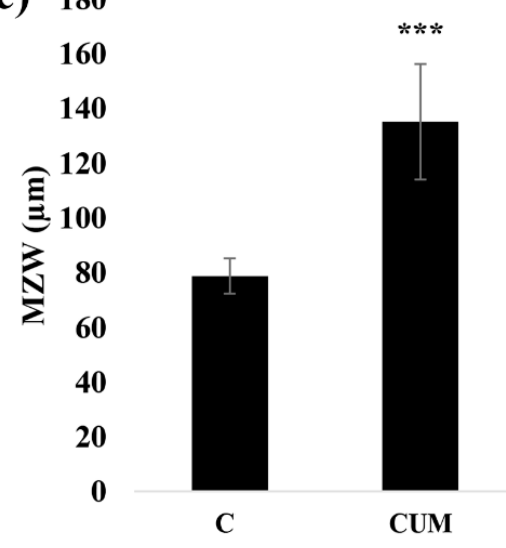

d)

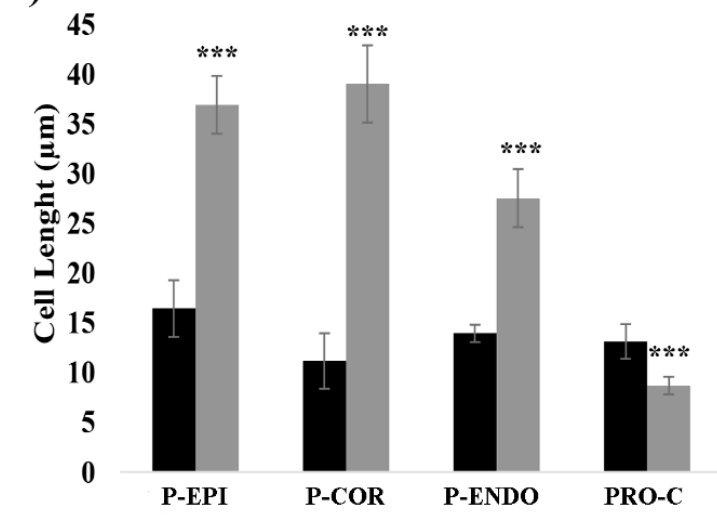

e) 70

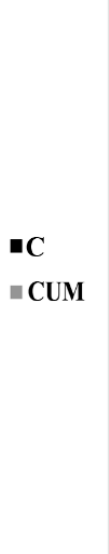

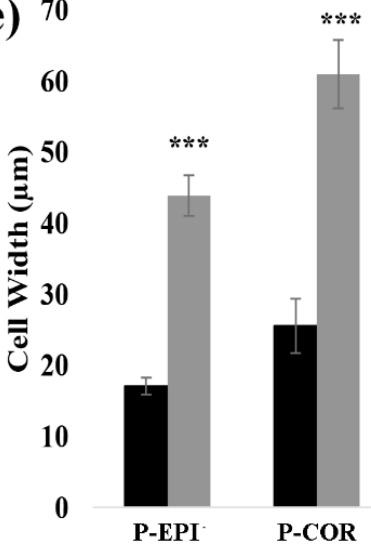

g) 160

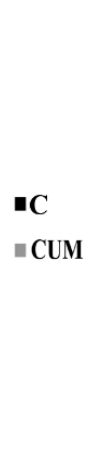

CW

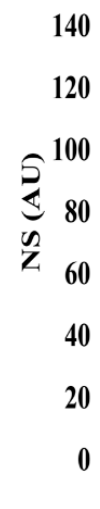

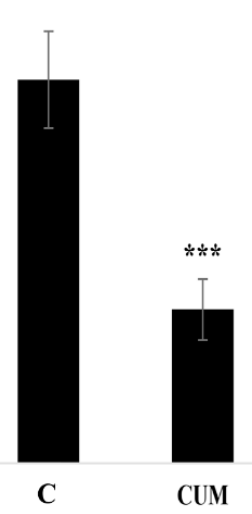

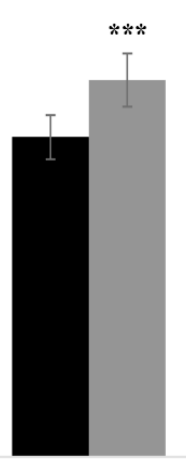

h) 12
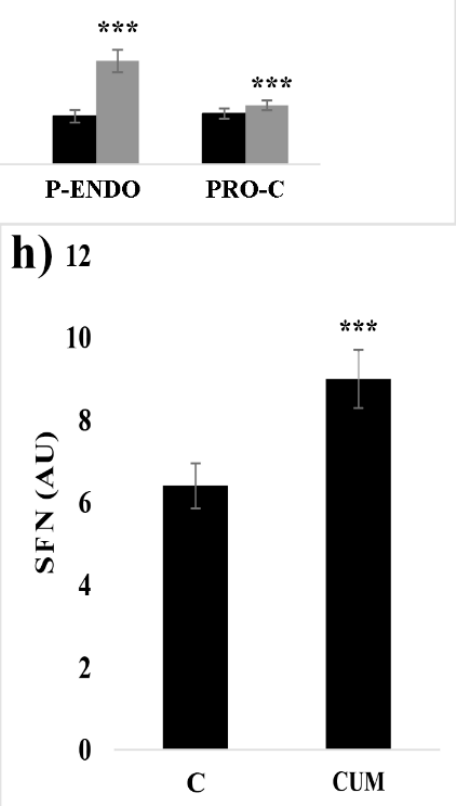

Figure 2. RAM morphology of 4 days old Arabidosis seedlings treated for 7 days with coumarin 0 (C) or 100 (CUM) $\mu$ M. (a) MCM-meristem cell number; (b) MZL—meristem zone length; (c) MZW—-meristem zone width; (d) cell length; (e) cell width; (f) CL—columella length; CW—columella width; (g) NS—number of statoliths; (h) SFN—procambium files number. Protodermis (P-EPI); precortex (P-COR); proendodermis (P-ENDO); procambium (PRO-C). Data are presented as mean \pm standard deviation (SD). Statistical analysis was performed using the Student's $t$-test with ${ }^{* * *} p \leq 0.001$. $N=20$. 

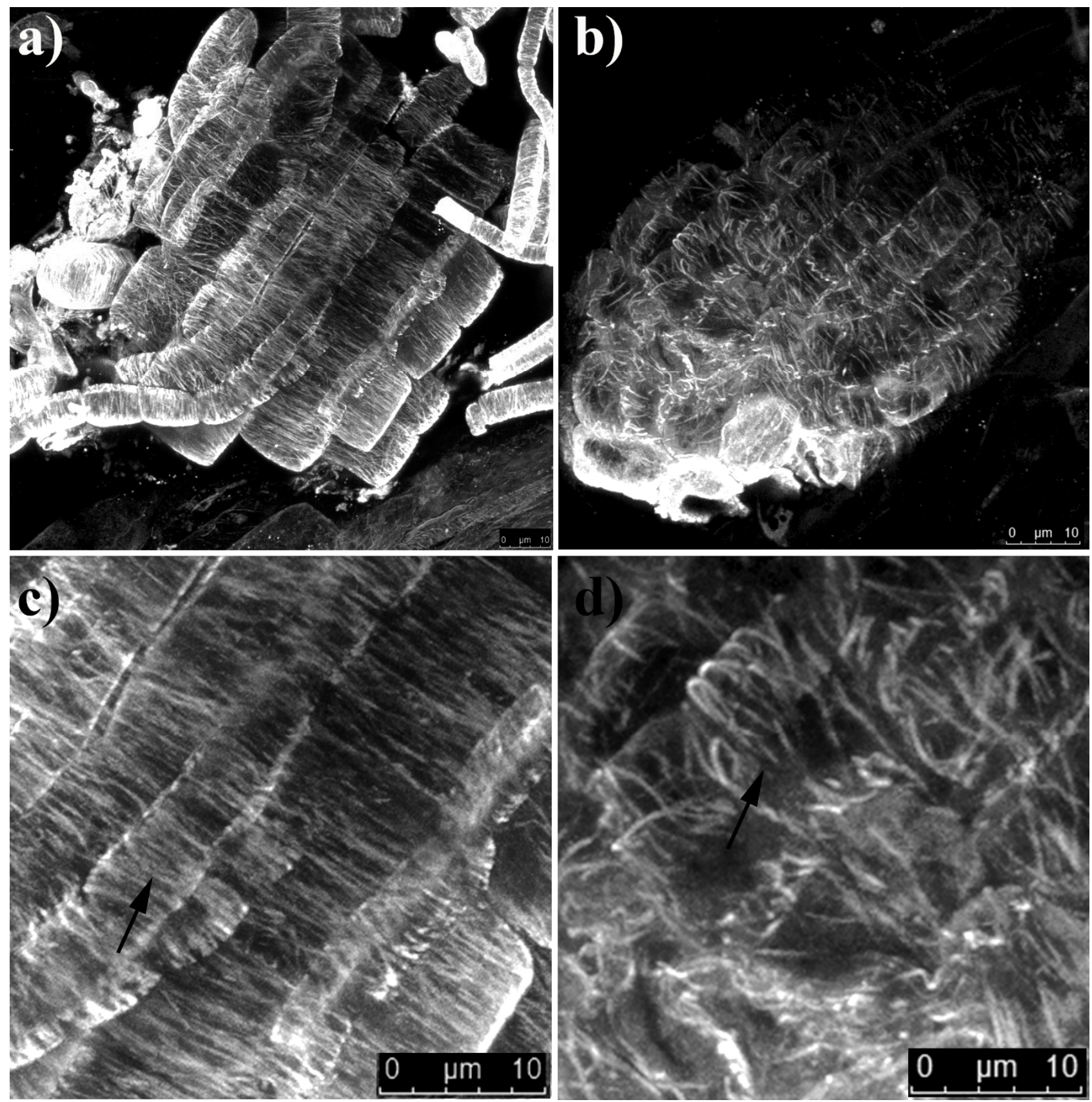

Figure 3. Microtubule immunostaining of 4 days old Arabidopsis roots treated for 7 days with coumarin. (a) Control cells $(0 \mu \mathrm{M}) ;(\mathbf{b})$ coumarin-treated cells $(100 \mu \mathrm{M}) ;(\mathbf{c}, \mathbf{d})$ zoomed-in view of a specific area of the images of $(\mathbf{a}, \mathbf{b})$, respectively, to make coumarin-induced microtubule alterations clearly visible. Black arrows (in (c,d)) indicate parallel, dense, and well-organized microtubules in the control cells and disorganized and lax microtubules in coumarin-treated cells. Scale bars (images a,b): $10 \mu \mathrm{m} . \mathrm{N}=20$.

\subsection{Effects of Coumarin on Cell Division}

Given that root-meristem size is determined by both the rate of cell differentiation and cell division rate [44-46], to assess whether a reduction in cell division could also cause the decline in RAM size, we analyzed either the mitotic index or cyclin B's turnover, which is an essential protein expressed during the G2 phase of the cell cycle, which is degraded during mitosis $[47,48]$.

The results reported highlighted a substantial reduction in dividing cells ( $55 \%$ lower than that of the control) (Figure 4a). The confocal microscopic analysis revealed that 
untreated Arabidosis seedlings showed a GFP-fusion cyclin B1;1 signal in some RAM cells (Figure $4 \mathrm{~b}$ ). In contrast, both the percentage of GFP-labeled cells and the relative intensity of the fluorescent signal slightly increased in roots treated with $100 \mu \mathrm{M}$ of coumarin (Figure 4c). Those results suggest a disturbance in cyclin B's degradation, resulting in abnormal mitosis in the RAM.
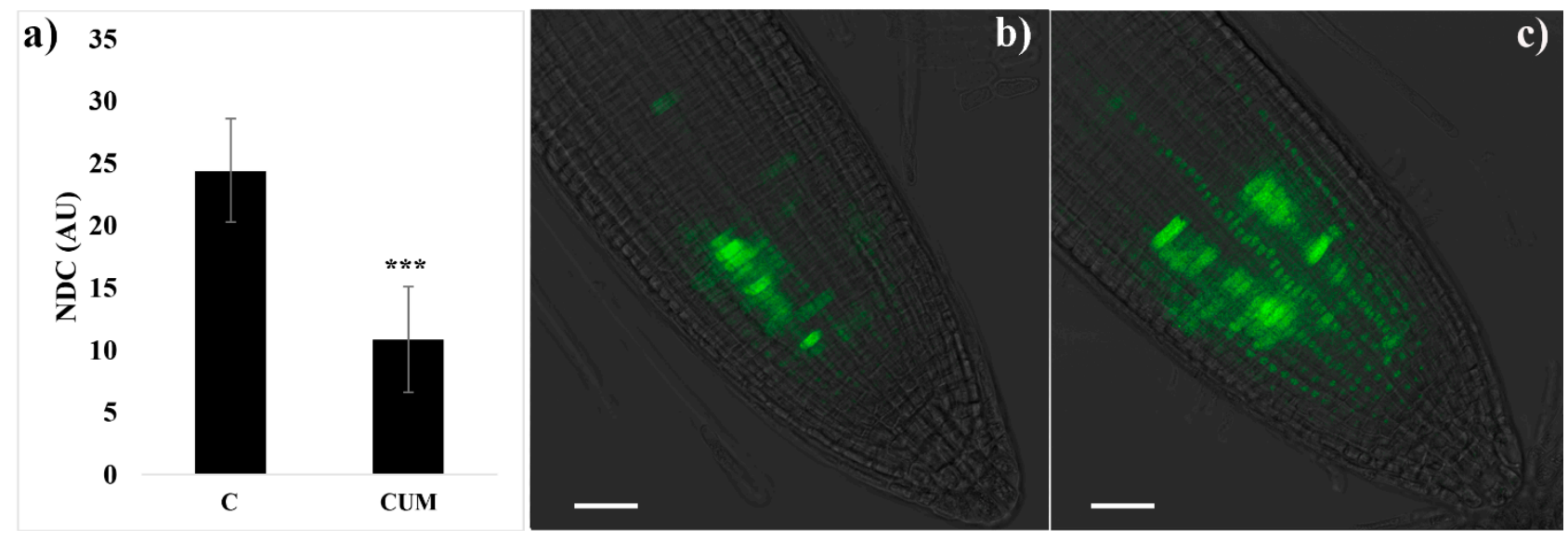

Figure 4. Effects of coumarin 0 (C) or 100 (CUM) $\mu \mathrm{M}$ on cell division in 4 days old Arabidopsis thaliana RAM. (a) Mitotic index expressed as the number of dividing cells (NDC). Data are presented as mean \pm standard deviation (SD). Statistical analysis was performed using the Student's $t$-test with ${ }^{* * *} p \leq 0.001 . \mathrm{N}=20$. $(\mathbf{b}, \mathbf{c})$ Confocal microscopy imaging of Arabidosis transgenic line cyclin B1;1::GFP in control (b) and treated (c) RAM. Scalebar $50 \mu \mathrm{m}$.

\subsection{Effects of Coumarin on Auxin Content and Polar Transport}

Previous research has suggested that the alterations observed on the root morphology of coumarin-treated $(100 \mu \mathrm{M})$ roots could be mediated by an alteration in the polar auxin transport [22]. Therefore, we decided to quantify the auxin content in the roots of seedlings exposed to coumarin for $48 \mathrm{~h}$ and monitor its effects on the principal auxin transporting proteins.

Auxin distribution and quantification were carried out on the full seedlings roots using the auxin-responsive reporter $p D R 5:: G F P$ and through a GC/MS approach. In contrast, coumarin's effects on auxin transporting proteins were evaluated using the previously described GFP transgenic lines (see Materials and Methods).

The monitoring of the auxin-responsive reporter $p D R 5:: G F P$ revealed that the $48 \mathrm{~h}$ coumarin treatment impaired auxin distribution. Indeed, in control roots, the $p D R 5$ dependent GFP distribution reflected the typical auxin maximum distribution in the root tip (i.e., QC, initial and mature columella cells) and procambium cells (Figure 5). In coumarin-treated roots, a significant weak decrease (7\%) in GFP signal intensity was observed in the root tip (Figure 5a,b,e). On the contrary, in the procambium at the MZ level, an increase in GFP intensity (73\% higher than that in the control) was observed (Figure 5c-e). Besides, an accumulation of GFP fluorescence (higher than that in control roots (Figure 5c) was observed locally in the elongation zone and along the entire root until the root and stem boundary, suggesting auxin accumulation (Figure 5d).

To verify the effects of long coumarin exposure on DR5 signal, we also carried out experiments on plants treated for 7 days, which confirmed a substantial impairment in GFP signal intensity (Figure S3a,b). In the columella of the coumarin-treated root, the GFP was widespread, whereas in the procambium we observed a signal higher than that in control, confirming what was observed after $48 \mathrm{~h}$ of treatment (Figure S3b). 


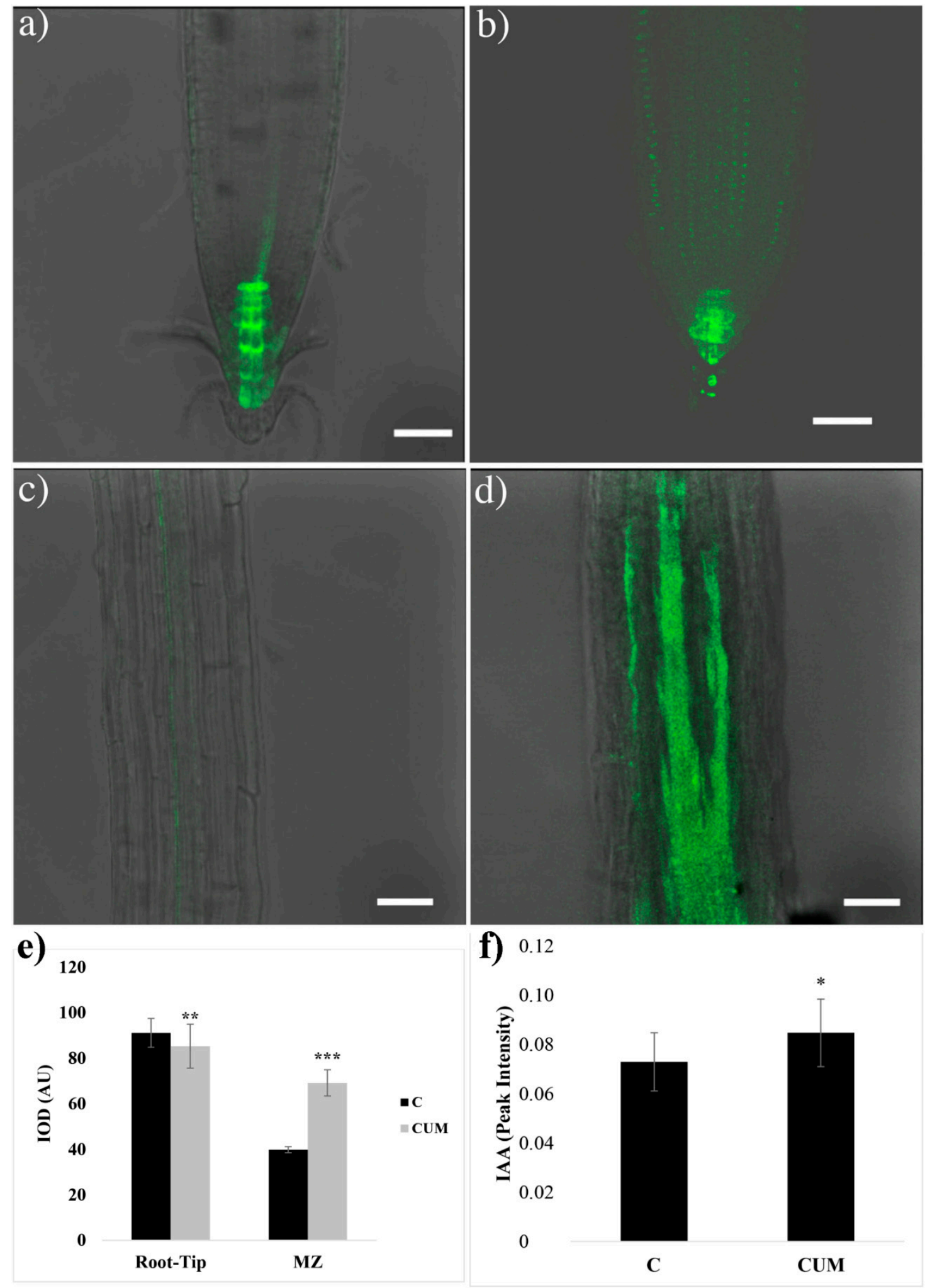

Figure 5. Fluorescence detection in 4 days old A. thaliana $p D R 5:: G F P$ transgenic line (auxin responsive reporter) grown for $48 \mathrm{~h}$ in untreated agar medium ((a) (RAM) and (c) (elongation zone)) or $100 \mu \mathrm{M}$ of coumarin enriched agar medium ((b) (RAM) and (d) (elongation zone)). Scale bars $34 \mu \mathrm{m} . \mathrm{N}=20$. (e) Integrated optical density (IOD) expressed as arbitrary units (AU) of fluorescence intensity measured in the root tip and the MZ (maturation zone) of Arabidosis treated for $48 \mathrm{~h}$ with 0 or $100 \mu \mathrm{M}$ of coumarin $(\mathrm{N}=10)$; (f) auxin content in Arabidosis roots treated for $48 \mathrm{~h}$ with coumarin 0 (C) or 100 $(\mathrm{CUM}) \mu \mathrm{M}$. Data are presented as mean \pm standard deviation (SD). Statistical analysis was performed using the Student's $t$-test with ${ }^{*} p \leq 0.05,{ }^{* *} p \leq 0.01,{ }^{* * *} p \leq 0.001 . \mathrm{N}=4$. 
Finally, the GC/MS auxin quantification pointed out, in $48 \mathrm{~h}$ coumarin-treated roots, an auxin accumulation (16\%) higher than that in control (Figure $5 \mathrm{f}$ ).

Based on these observations, PINs::PINs-GFP (auxin efflux carriers) transgenic lines were used to monitor the location of the auxin transporters in coumarin-treated and untreated root tips (Figure 6a-j). Interestingly, the distribution pattern of three PIN proteins appeared strongly affected by coumarin treatment, showing an altered distribution, as well as a reduction in their presence.

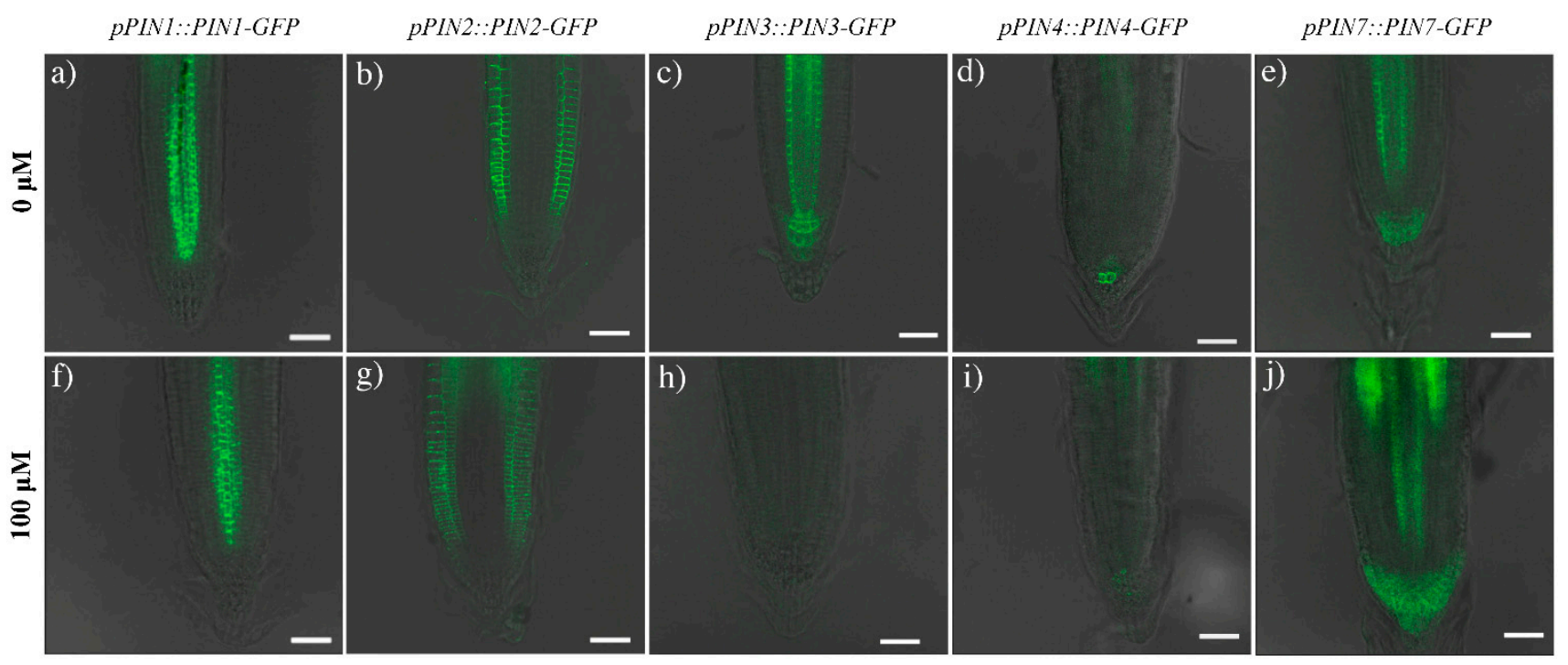

Figure 6. Images of the RAM in 4 days old seedlings of $A$. thaliana transgenic lines ( $p$ PIN1::PIN1-GFP (a,f), pPIN2::PIN2-GFP $(\mathbf{b}, \mathbf{g}), p P I N 3:: P I N 3-G F P(\mathbf{c}, \mathbf{h}), p P I N 4:: P I N 4-G F P(\mathbf{d}, \mathbf{i}), p P I N 7:: P I N 7-G F P(\mathbf{e}, \mathbf{j}))$ treated for $48 \mathrm{~h}$ with coumarin $0(\mathbf{a}-\mathbf{e})$ or $100 \mu \mathrm{M}$ $(\mathbf{f}-\mathbf{j})$. Scale bars $30 \mu \mathrm{m} . \mathrm{N}=20$.

In untreated roots, PINs proteins were characterized by a classical presence and distribution. As detailed in the bibliography [28], PIN1 is mainly situated at the basal end of provascular stelar and proendodermal cells (Figure 6a). PIN2 is localized basally in the procambium cells, the protodermal cells' apical side, and the lateral root cap (Figure 6b). PIN3 is expressed in the columella, at the basal side of vasculature cells, and at the lateral side of the pericycle cells of the elongation zone (Figure 6c). PIN4 is localized in the stem cell niche and basally in provascular cells (Figure 6d). Finally, PIN7 resides at the lateral and basal membranes of provascular cells in the meristem and elongation zone (Figure 6e). In contrast, in columella' cells, it coincides with the PIN3 domain [49] (Figure 6c,e). In plants treated with coumarin, no significant differences were observed in the PIN1 and PIN2 distribution along the RAM after $48 \mathrm{~h}$ of coumarin treatment. The GFP intensity was reduced by $16 \%$ and $32 \%$, respectively (Figures $6 a, b, f, g$ and 7 ). The GFP fluorescence in PIN3 (IOD 81\% lower than that in control) and PIN4 (IOD 72\% lower than that in control) was absent (Figures 6c,d,h,i and 7), whereas in PIN7, the GFP signal was highly intense in the basal side of the procambium cells and widespread in columella's cells (Figure 6e,j), pointing out an increase in IOD that was $23 \%$ higher than that in control (Figure 7). 


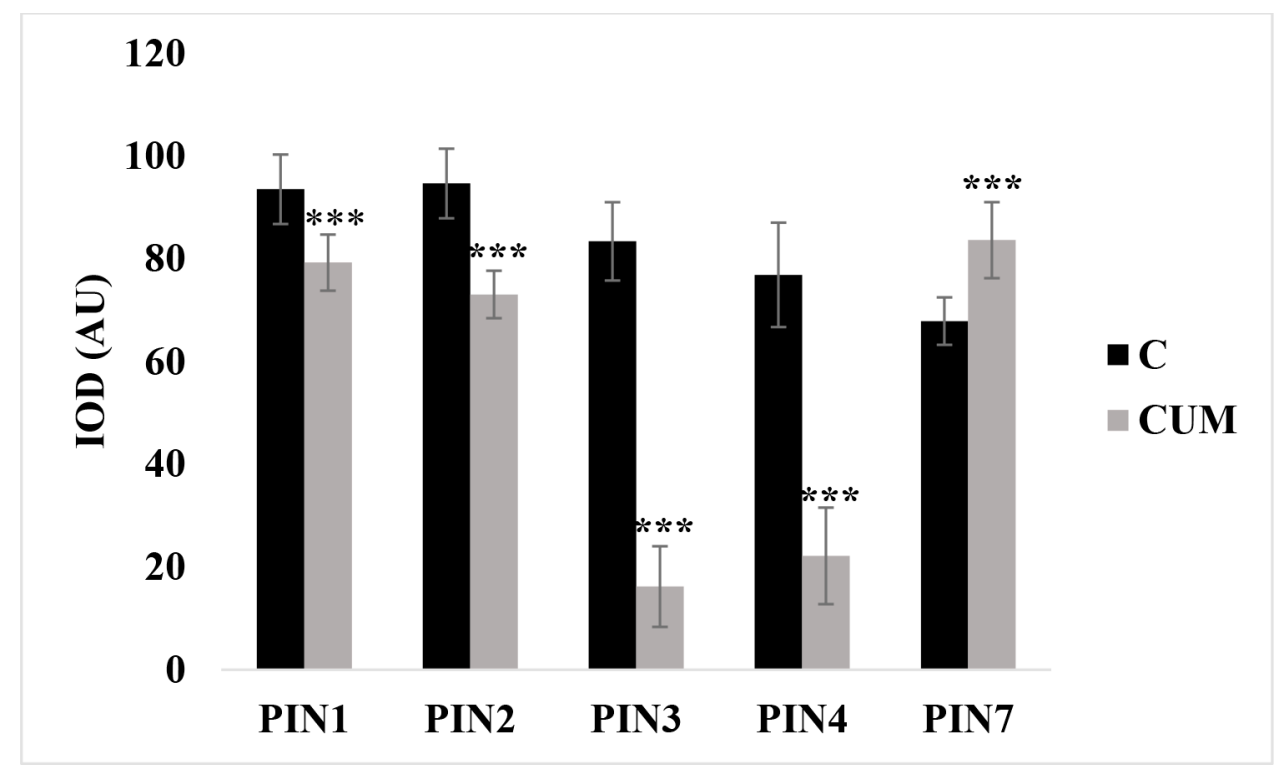

Figure 7. Integrated optical density (IOD) of PINs proteins expressed as arbitrary units (AU) of fluorescence intensity measured on the entire RAM of Arabidosis treated for $48 \mathrm{~h}$ with coumarin 0 (C) or 100 (CUM) $\mu \mathrm{M}$. Data are presented as mean \pm standard deviation (SD). Statistical analysis was performed using the Student's $t$-test with ${ }^{* * *} p \leq 0.001$. $N=10$.

\section{Discussion}

In recent years, to reveal the effects of natural compounds on phytohormone pathways and their interference on plant growth and development, the model plant $A$. thaliana and its various mutants and transgenic lines have been widely employed.

In the present study, we evaluated coumarin's effects on auxin biosynthesis and distribution by testing its effects on the root development of WT Arabidosis seedlings. Moreover, we assessed this molecule's possible interaction with microtubule organization and its potential impact on auxin transport.

Coumarin's phytotoxicity and its ability to alter both root anatomy and morphology have been primarily documented [12,50]. Previous studies have demonstrated that this molecule is a potent inhibitor of germination and seedling growth and development [51,52]. On the contrary, at relatively low concentrations $(100 \mu \mathrm{M})$, it significantly stimulates lateral root and root hair production, whereas the total root length is significantly reduced [22]. Similar effects (reduction in primary root growth, increase in lateral root number, and root hair density) have generally been observed on Arabidosis seedlings treated with exogenous auxins such as IAA, 2,4-D, and NAA [53]. Due to that, it has been widely speculated that coumarin at low concentrations could exert an auxin-like effect $[18,20]$, and recent studies have reported that coumarin's effects are probably due to an alteration in the polar auxin transport [22]. In particular, Lupini et al. [22], using several auxin influxes and efflux mutants (aux1-22, lax3, pin1, eir1-4, and pin3-5), hypothesized that coumarin treatment $(100 \mu \mathrm{M})$ could modulate root development interacting with the polar auxin transport. However, no further studies have been carried out to explore this potential mode of action in depth.

In this study, we demonstrated that coumarin's effect is anything but an effect similar to auxin. The alterations induced by this molecule are, according to our data, a substantial alteration in the root tips cortical microtubule organization accompanied by an alteration in cell division and auxin transport, synthesis, and its PINs-mediated distribution.

Coumarin treatments induced a reduction in cell division and alteration in RAM organization. The RAM of treated plants was characterized by swollen protodermal and procambium cells, which expanded radially more than longitudinally. Moreover, a reduction in the RAM (formed by a lower number of cells than that in control) and an increase in its width were observed, suggesting an advancement of transition and 
differentiation zones. The reduction in meristem size is commonly observed in plants treated with natural products, heavy metals, and xenobiotics [40,54]. For example, a reduction in RAM size was observed in Arabidosis seedlings treated with brassinolide, farnesene, and narciclasine $[40,44,55]$. Besides, in plants treated with cadmium, early differentiation of meristematic cells was induced by a premature cell cycle exit from the meristematic zone [50].

In coumarin-treated seedlings, the reduction in meristem size was accompanied by an accumulation of CYCLIN B1;1, suggesting that coumarin could have affected the meristematic activity, resulting in the loss of cell division potential in the root. Previous studies have demonstrated that coumarin negatively affects mitosis in almost all phases, inducing chromosomal aberrations, binucleated cells, incomplete phragmoplasts, and DNA damages [56,57]. Culligan et al. [58] reported that DNA damaging agents could induce, as also observed in our experiments, the accumulation of CYCLIN B1;1, as well as root swelling. Moreover, Wu et al. [59], using the Arabidosis mutant radially swollen 4 (RSW4) (a mutant with swollen root due to microtubule disorganization), suggested that CYCLIN B1;1 accumulates in response to DNA damages [60] or DNA damaging agents [58,61]. Besides, they observed that the superabundant cyclin is associated with altered root histology and root swelling mediated by microtubule disorganization. The hypothesis that CYCLIN B1;1 accumulation could induce an alteration in the microtubule cortical array organization was further confirmed by Weingartner et al. [62] in transgenic tobacco expressing a nondegradable version of CYCLIN B1;1 and by Serralbo et al. [63] using the hobbit mutant of $A$. thaliana characterized by a reduced function of the complex responsible for CYCLIN B1;1 degradation. Both mutant and transgenic lines were characterized by microtubule disorganization and swollen cell shape, supporting the idea that CYCLIN B1;1 accumulation disrupts cortical microtubules. Despite the evidence that CYCLIN B1;1 accumulation could alter microtubule organization, the possibility that these effects are directly induced by coumarin and not a consequence of pleiotropic effects at the moment is just speculation, which should be explored in depth.

The swelling phenomenon, generally accompanied by a reduction in RAM length, has mainly been observed in plants treated with microtubule interferents (stabilizers and destabilizers) such as colchicine, taxol, and oryzalin [64,65]. In particular, colchicine interferes with microtubule dynamics, blocking polymerization at the end of the mitotic spindle, leading to metaphase arrest [66]. In contrast, oryzalin binds to plant tubulin, preventing its polymerization and making extant microtubules more likely to depolymerize $[64,67,68]$. The effects of both molecules on root tip anatomy are similar to the effects induced by coumarin. The images of Arabidosis root tips presented by Baskin et al. [65] perfectly overlap with the effects observed in coumarin-treated plants. Those results suggest that coumarin might interact with the organization of microtubule arrays. The hypothesis was further confirmed by the immunolabeling bioassay, where microtubules of treated plants appeared fragmented and erratically arranged.

As the reduction in cell division and primary root growth, the increment in lateral root number, and the increase in root hair length and density are typical effects of plants treated with auxin and auxinic herbicides [69-71], we decided to investigate the effects of coumarin on both auxin content and transport. Moreover, Li et al. [72], using the hydroxycoumarin 4-methyl-umbelliferone, observed an auxin accumulation in Arabidosis-treated root that mediated F-actin disruption and, as a consequence, malformation of the RAM. Furthermore, it is known that auxin plays a pivotal role in the maintenance of root distal stem cell identity, and alterations in its balance could result in the loss of the QC identity, as well as an alteration in the cellular organization of the RAM in Arabidosis [73]. The GC-MS-driven relative quantification of auxin content pointed out a slight increase in this plant hormone in treated roots. This increase could justify the previously reported coumarin-induced stimulation of peroxidase and IAA-oxidase activity (enzymes involved in IAA catabolism) [74]. As well as coumarin, scopoletin (a natural coumarin with auxin-like activity and a chemical structure remarkably similar to the simple coumarin [7] at low concentrations inhibited 
auxin's catabolism, causing its accumulation [75]. Simultaneously, as coumarin, it has been proven that the same molecule stimulated IAA oxidase activity [75]. Both molecules probably promote auxin accumulation, which activates IAA-oxidase activity to restore its concentration to physiological levels.

The auxin gene reporter DR5::GFP further suggested that coumarin also induced an alteration in its distribution as, in treated plants, a high GFP signal was observed in the elongation and maturation zone, as well as a weak reduction in the RAM. Casimiro et al. [76] demonstrated that auxin accumulation in the maturation zone is pivotal for lateral root production. They showed that the acropetal polar transport inhibitor NPA (N-1naphthylphthalamic acid) induced IAA accumulation in the root apex and its reduction in basal tissues critical for lateral root initiation. They concluded that both root and shoot and root acropetal and basipetal auxin transport activities are required during the initiation and emergence phases of lateral root development. In addition, De Rybel et al. [77], using the synthetic non-auxin probe naxillin, a molecule that stimulates lateral root formation, reported (as also observed in our experiments) that $24 \mathrm{~h}$ of treatment with this molecule induced both the synthetic auxin-responsive marker $p D R 5$ ::GUS locally in the maturation zone (specifically in xylem pole cells adjacent to the pericycle) and CYCLIN B1;1. They also demonstrated that the naxillin-auxin accumulation in roots was due to the naxillin-induced conversion of the auxin precursor indole-3-butyric acid into the active auxin indole-3acetic acid. Besides, it has also been demonstrated that the induction of CYCLIN B1;1 expression coincides with the formation of a new lateral root primordium and, thus, lateral root development $[78,79]$. These results suggest that coumarin could alter auxin's polar transport and synthesis by inducing auxin accumulation in the elongation and maturation zone of the root, activating the physiological and biochemical mechanisms involved in lateral roots production.

Previous studies focusing on the effects of microtubule de-polymerizing agents demonstrated that these molecules could interfere with auxin polar efflux transporters. In particular, oryzalin visibly interfered with PIN1 (in the procambium) and PIN2 (in young cortex cells), resulting in reduced auxin's polar distribution. These findings indicated that intact microtubules are pivotal for proper auxin polar trafficking in plant cells [32]. In contrast to what was observed with oryzalin, coumarin did not affect the distribution of PIN1 and PIN2, but significantly reduced the protein abundance. On the contrary, it completely suppressed PIN3 and PIN4 protein abundance. Those results suggest that coumarin specifically inhibited the acropetal auxin flux in the procambium, in the columella cells (PIN3), and from the central RAM toward the quiescent center (PIN4). Therefore, auxin procurement to the RAM was only guarded by PIN1 and PIN7, which justifies the presence (even if lower than that in the control) of auxin in the root tip. The alteration in auxin balance observed at the quiescent center level could confirm our hypothesis that coumarin could induce the loss of the root distal stem cell identity and could justify the lack of columella cell expansion, resulting in a reduced columella area in treated roots. Moreover, the alteration in the local auxin maximum/gradient within the RAM, which is generated by the PIN directional auxin transporters, could be the reason for the reduction in statolith observed in coumarin-treated roots. In fact, Zhang et al. [80] demonstrated that auxin regulates the expression of three key starch granule synthesis genes involved in statolith production. Finally, the diffuse GFP signal observed in PIN7 in the elongation zone, as confirmed by the DR5 auxin reporter, suggests auxin accumulation in the elongation zone and particularly in the maturation zone of the root, where lateral root initiation occurs. It is known that auxin regulates root system architecture by promoting the acquisition of founder cell identity in pericycle cells $[81,82]$ and by stimulating LR development $[76,83]$. 


\section{Materials and Methods}

\subsection{Reagents Used}

All the reagents used in the following experiments (EtOH, NaCLO, MES, Triton X-100, plant agar, propidium iodide, Schiff reagent, among others) were purchased from Sigma Aldrich S.r.l. (Via Monte Rosa, Milano, Italy).

\subsection{Plant Material and Growth Conditions}

Seeds of Arabidopsis thaliana (L.) Heynh. Ecotype Columbia (Col-0) and pDR5::GFP [28], pPIN1::PIN1-GFP [84], pPIN2::PIN2-GFP [49], pPIN3::PIN3-GFP [49], pPIN4::PIN4-GFP [49], pPIN7::PIN7-GFP [49], and cyclin B1;1::GFP [85] transgenic lines were used for the experiments. Seed sterilizations, growth conditions, and treatments were carried out as previously described by Lupini et al. [22], with some modifications.

Seeds were surface-sterilized for $3 \mathrm{~min}$ in $50 \% \mathrm{EtOH}$, and they were then washed for $3 \mathrm{~min}$ in a $\mathrm{NaOCl}$ solution $(0.5 \%)$ enriched with Triton X-100 at $0.01 \%$. Finally, sterilized seeds were washed three times in sterilized Milli-Q water and, to break dormancy and synchronize germination, were then maintained in a $0.1 \%$ agar solution at $4{ }^{\circ} \mathrm{C}$ for $48 \mathrm{~h}$. Twenty-four seeds were then placed in square Petri dishes $(100 \times 150 \mathrm{~mm})$ containing agarised $(0.8 \% w / v)$ basal medium enriched with micro and macronutrients, plus sucrose $(0.5 \%(w / v))$, MES $\left(1 \mathrm{~g} \mathrm{~L}^{-1}\right), \mathrm{pH} 5.75$ [22].

Petri dishes were placed vertically in a growth chamber at $22{ }^{\circ} \mathrm{C}, 65 \%$ relative humidity, 16 (light) $/ 8$ (dark) $\mathrm{h}$ photoperiod, and $300 \mu \mathrm{mol}$ photon flux density $\mathrm{m}^{-2} \mathrm{~s}^{-1}$. Five 4 days old seedlings (per treatment and replicate), chosen by uniformity were then transplanted for seven days (long-term experiment) or $48 \mathrm{~h}$ (short-term experiment) in the agar medium previously described enriched with coumarin 0 (control) and $100 \mu \mathrm{M}$ of coumarin (treatment).

\subsection{Long-Term Experiments}

To highlight drastic changes induced by coumarin on the Arabidosis root apical meristem (RAM) and cortical microtubule organization, otherwise not visible during shorttreatments, 4 days old Arabidosis seedlings were treated with coumarin for 7 days.

\subsubsection{Root Anatomy: Meristem Size Analysis}

For the analysis of the RAM, A. thaliana (Col-0) seedlings, for each treatment (coumarin 0 or $100 \mu \mathrm{M})$ and replication $(\mathrm{N}=20)$, were fixed, stained with propidium iodide, and imaged by confocal microscopy according to Gonzàlez-Garcìa et al. [86].

At the end of the experiment, the following parameters were evaluated: (i) the number of cells composing the RAM (MCN), calculated counting the number of precortex cells extending from the quiescent center (QC) to the first elongated cortex cell; (ii) Meristem length (MZL), expressed as the distance $(\mu \mathrm{m})$ from the $\mathrm{QC}$ to the first elongated cortex cell; (iii) RAM width (MZW), considered the distance between the two lines of cortex cells; (iv) the length and width of protodermal, precortical, and proendodermal cells; (v) the length (CL) (measured from the QC to the bottom of the columella) and width (CW) (measured at the QC level) of the columella; (vi) the columella (CA) area, considered as the total area of cells presenting statoliths.

A parallel experiment using colchicine $(200 \mu \mathrm{M})$ was carried out to compare the effects of coumarin with a known microtubule polymerizing agent.

\subsubsection{Microtubules Immunolabeling}

According to the method of Holzinger et al. [87], the microtubule immunolabeling was carried out with some modifications. After coumarin treatment $(0$ or $100 \mu \mathrm{M})$, A. thaliana root tips were excised and fixed at room temperature for $45 \mathrm{~min}$ in PEM buffer ( $50 \mathrm{mM}$ of PIPES, $2 \mathrm{mM}$ of EGTA, $2 \mathrm{mM}$ of $\mathrm{MnSO}_{4} ; \mathrm{pH} 7.2$ ) containing $0.5 \%$ glutaraldehyde, $1.5 \%$ formaldehyde, and $0.1 \%$ Triton X-100. 
Roots were successively washed for $20 \mathrm{~min}$ in the same buffer and then again in PEM buffer. Fixed roots were chopped into small pieces and digested, at room temperature for $30 \mathrm{~min}$, with cellulase and pectolyase Y-23 (1\%) solubilized in PEM buffer (pH 5.5). After the digestion step, samples were washed in PEM buffer ( $\mathrm{pH}$ 7.2) and incubated for $10 \mathrm{~min}$ at $-20{ }^{\circ} \mathrm{C}$ in methanol. The samples were successfully washed with phosphate buffer saline (PBS) (pH 7.4) and incubated for $20 \mathrm{~min}$ with $1 \mathrm{mg} \mathrm{mL}^{-1}$ of sodium borate in PBS. Samples were then further washed with PBS and incubated with $1 \%$ bovine serum albumin and $50 \mathrm{mM}$ of glycine in PBS. After a final washing in PBS, the samples were incubated overnight with the primary antibody (anti- $\alpha$ tubulin B 5-1-2, Sigma-Aldrich, 1:1000 in PBS) at $4{ }^{\circ} \mathrm{C}$, which was removed by three consecutive washes in PBS. The samples were then incubated with the secondary antibody (Alexa 488-conjugated goat anti-mouse IgG, Sigma-Aldrich, 1:200 in PBS) at $37^{\circ} \mathrm{C}$ for $3 \mathrm{~h}$. Besides, negative controls were performed alternately using the primary and secondary antibodies alone (data not shown).

Finally, immunolabelled roots were mounted in the Citifluor AF1 antifade agent to avoid fluorescence degradation. Visualization of the microtubules was performed using a Leica TCS SP5 confocal microscope (Wetzlar, Germany) with a 63X oil immersion objective and a $496 \mathrm{~nm}$ excitation wavelength (argon laser); and they were photographed with a LAS-AF software. The experiments were carried out with 20 replicates.

\subsection{Short-Term Experiments}

To avoid biased interpretation, due to cascade effects connected to prolonged exposure to the molecule, the experiments on cellular division, PINs proteins, and auxin quantification were carried out using a short exposure $(48 \mathrm{~h})$ of the seedlings to coumarin.

\subsubsection{Mitotic Indices and Cyclin B1;1::GFP Localization}

Cell division was observed by confocal microscopy (see the method described below in $\S$ localization of GFP signal in Arabidopsis's primary roots) on the cyclin B1;1::GFP transgenic line treated for $48 \mathrm{~h}$ on the previously described agarized medium enriched with coumarin 0 or $100 \mu \mathrm{M}$.

The evaluation of mitotic indices in A. thaliana RAMs treated for $48 \mathrm{~h}$ with coumarin 0 or $100 \mu \mathrm{M}$ was carried out as previously described by Cools et al. [88] with some modifications. In particular, the synchronization of root cell division was obtained by incubating the seedlings for $24 \mathrm{~h}$ in a hydroxyurea solution $(2 \mathrm{mM}, \mathrm{pH}$ 6.0). After incubation, Arabidosis seedlings were washed in deionized water and transferred in a continuously aerated coumarin solution $(0$ or $100 \mu \mathrm{M})$ for $48 \mathrm{~h}$. Seedlings were then collected, and RAMs were cut with a razor blade and then fixed in a solution composed of acetic acid, ethanol, and chloroform (6:1:3) with iron traces.

Samples were immediately stored at $-20^{\circ} \mathrm{C}$ for $24 \mathrm{~h}$. After that, the fixing solution was renewed (no iron traces were added this time), and the samples were stored at $-20{ }^{\circ} \mathrm{C}$ for four days. After fixing, to allow cells and chromosomes dispersion, samples were hydrolyzed at $60^{\circ} \mathrm{C}$ for $20 \mathrm{~min}$ in $\mathrm{HCl} 1 \mathrm{~N}$. Then, to stain the chromosomes, RAM samples were immersed in Schiff reagent and placed under dark conditions for $2 \mathrm{~h}$ at room temperature. Finally, the reaction was stopped with a few drops of acetic acid, and the samples were mounted on a microscope slide and fixed, passing the mounted slide on a flame for $3 \mathrm{~s}$. A total of 1000 cells were counted in between 30 and 40 meristems per treatment. Samples were observed using an Olympus BX41 optical microscope $(100 \times$ objective $)$.

\subsubsection{Localization of GFP Signal in Arabidosis's Primary Roots}

The experiments on $p$ DR5::GFP, $p$ PINs::GFP were carried out on 4 days old seedlings transplanted for $48 \mathrm{~h}$ on agar medium enriched with coumarin (short-term experiment). Treated and untreated $A$. thaliana (Col-0) seedlings were collected, fixed, and mounted as previously described [40].

Confocal images of median longitudinal sections were obtained using a Leica inverted TCS SP8 confocal scanning laser microscope equipped with a $40 \times$ oil immersion objective. 
The detection of green fluorescent protein (GFP) (excitation peak centered at about $488 \mathrm{~nm}$ and the emission peak wavelength of $509 \mathrm{~nm}$ ) was performed by combining the microscope's sequential scanning facility's settings. More than 40 seedlings were analyzed per treatment, and five independent experiments were carried out. Channel settings for GFP and laser power were kept identical during the analysis of all samples to make the results comparable.

To evaluate auxin and PIN protein abundance, the GFP signal intensity was measured by quantifying the integrated optical density (IOD) parameter on the root tip and maturation zone, using the software ImagePro Plus (Media Cybernetics, Inc. 1700 Rockville Pike, Suite 240 Rockville, Rockville, MD, USA). The measurements have been obtained using the "Count/Size" tool. First, all the green signals in the area of interest have been manually selected using the tool "Intensity Range Selection." Successively, the IOD of the entire green selected area has been measured on the root tip and maturation zone for the pDR5::GFP transgenic line and on the entire root apex for the PINs.

\subsubsection{Auxin Quantification}

Auxin quantification was carried out on Arabidosis seedlings treated with coumarin $(0$ or $100 \mu \mathrm{M}$ ) for $48 \mathrm{~h}$. The entire root of control or treated seedlings was excised, immediately snap-frozen in liquid nitrogen (to quench the metabolism), and powdered. One hundred milligrams of plant material was used for sample extraction and derivatization. Samples were derivatized and analyzed using a GC-MS apparatus following the protocol described by Rawlinson et al. [89] with some modifications.

To the powdered samples, a $20 \mu \mathrm{L}$ solution of 3-indolepropionic acid (IPA $20 \mathrm{mg} / \mathrm{mL}$ ) was added as the internal standard for relative quantification and normalization purposes. Successively, $147 \mu \mathrm{L}$ of methanol $(\mathrm{MeOH}), 34 \mu \mathrm{L}$ of pyridine, and $200 \mu \mathrm{L}$ of $\mathrm{NaOH}(1 \% w / v)$ were added, and the samples were shaken for $40 \mathrm{~s}$. After extraction, samples were derivatized using $20 \mu \mathrm{L}$ of methyl chloroformate and shaking for $30 \mathrm{~s}$ (this step was repeated two times). To the derivatized samples, $400 \mu \mathrm{L}$ of chloroform and $400 \mu \mathrm{L}$ of a $\mathrm{NaHCO}_{3}$ solution (50 mM of stock) were added, and the samples were shaken again for $1 \mathrm{~min}$ and centrifuged at 14,000 rpm per $1 \mathrm{~min}$. An aliquot $(100 \mu \mathrm{L})$ of the organic lower phase was collected and used for gas chromatography-mass spectrometry (GC-MS) analysis. A parallel experiment was carried out using, as an external standard, pure IAA for the assignment of the retention time.

GC-MS analysis was carried out using a Thermo Fisher gas chromatograph apparatus (Trace 1310) equipped with a single quadrupole mass spectrometer (ISQ LT) (Thermo Fisher Scientific, Str. Rivoltana, Km 4, 20090 Rodano, Milan, Italy). The capillary column (MEGA-5MS $30 \mathrm{~m} \times 0.25 \mathrm{~mm} \times 0.25 \mu \mathrm{m}+10 \mathrm{~m}$ pre-column) and the carrier gas was helium with a flow rate of $1 \mathrm{~mL} / \mathrm{min}$. The injector and transfer line were set at $250{ }^{\circ} \mathrm{C}$ and $270{ }^{\circ} \mathrm{C}$, respectively. Samples $(3 \mu \mathrm{L})$ were injected with a 35 psi pressure pulse, which was held for $1 \mathrm{~min}$. The following GC temperature program was used: Isocratic for $1 \mathrm{~min}$ at $40{ }^{\circ} \mathrm{C}$, from $40{ }^{\circ} \mathrm{C}$ to $320^{\circ} \mathrm{C}$ at a rate of $20{ }^{\circ} \mathrm{C} \mathrm{min}-1$, and then held isocratic for $2 \mathrm{~min}$ at $320^{\circ} \mathrm{C}$. The ion source was set to $200{ }^{\circ} \mathrm{C}$, and the solvent delay was $4.5 \mathrm{~min}$. Mass spectra were recorded in electronic ionization (EI) mode at $70 \mathrm{eV}$, scanning at a 50-400 m/z range to select appropriate EI mass fragments for each analyte. Then, the MS was run in selected ion monitoring (SIM) using one quantifier $(\mathrm{m} / \mathrm{z})$ and two qualifiers $(\mathrm{m} / \mathrm{z})$ ions. In particular, for IAA-methyl ester, the ions 189, 103, and 77 were selected for quantification. IAA identification and quantification were performed by comparing the RT with the IAA external standard and the mass spectra in the National Institute Standard and Technology (NIST 2011) spectral library. The relative IAA quantification was carried out by normalizing the IAA peak intensity with the intensity of the internal standard.

\subsection{Statistical Analysis}

A completely random design with 20 replications (4 for IAA quantification and 10 for the measurement of the GFP signal intensity) was adopted. Data were first checked for 
deviations from normality ( $\mathrm{D}^{\prime}$ Agostino-Pearson test) and tested for homogeneity (Leven Median test). The significance of differences between data sets was evaluated by the Student's test $(p \leq 0.05)$.

All anatomical measurements were carried out using the open-source software ImageJ.

\section{Conclusions}

The results suggest that coumarin strongly affects the RAM morphology of Arabidopsis thaliana, altering the microtubule cortical array organization, and unbiasing auxin biosynthesis and distribution. Coumarin, as also reported for other microtubule de-polymerizing drugs (e.g., oryzalin), through the alteration in IAA efflux carriers distribution, altered the normal acropetal transport of auxin from the maturation zone to the apical RAM, which was guaranteed only by PIN1 and PIN7. Consequently, it resulted in an auxin accumulation in the maturation zone's pericycle cell, inducing lateral root formation.

Further studies will focus on understanding whether coumarin acts as a microtubule polymerizing or depolymerizing agent, as well as on studying the signaling involved in response to coumarin using mutants characterized by cyclin and microtubule alterations. Moreover, we will study coumarin's effects through combined-omics approaches.

Supplementary Materials: The following are available online at https:/ /www.mdpi.com/article/10 $.3390 / \mathrm{ijms} 22147305 / \mathrm{s} 1$.

Author Contributions: Conceptualization, F.A. and L.B.; methodology, F.A. and L.B.; software, F.A. and L.B.; validation, A.M., B.M.-M., L.C.-F., M.L.M., M.M. and E.T.; formal analysis, A.M., B.M.-M., L.C.-F., M.M., M.L.M. and E.T.; investigation, F.A., L.B., L.L. and A.S.; resources, F.A. and L.B.; data curation, F.A., L.B., L.L. and A.S.; writing and original draft preparation, F.A., L.B., L.L. and A.S.; writing-review and editing, A.M., B.M.-M., L.C.-F., M.L.M. and E.T.; visualization, A.M., B.M.-M., L.C.-F., M.L.M. and E.T.; supervision, F.A. and L.B.; project administration, F.A. and L.B.; funding responsible, F.A. All authors have read and agreed to the published version of the manuscript.

Funding: This research was supported by the Ministerio de Ciencia, Innovaciòn y Universidades RTI2018-094716-B-100.

Institutional Review Board Statement: Not applicable.

Informed Consent Statement: Not applicable.

Data Availability Statement: Not applicable.

Acknowledgments: We would like to thank Jiri Friml, Hyung-Taeg Cho, Ikram Blilou, and Marcus Heisler, who gently provided the mutated lines used in the experiments.

Conflicts of Interest: All authors have read and agreed to the published version of the manuscript. The authors declare that the research was conducted in the absence of any commercial or financial relationships that could be construed as a potential conflict of interest.

\section{References}

1. Delgoda, R.; Murray, J. Evolutionary perspectives on the role of plant secondary metabolites. In Pharmacognosy; Elsevier: Amsterdam, The Netherlands, 2017; pp. 93-100.

2. Theis, N.; Lerdau, M. The evolution of function in plant secondary metabolites. Int. J. Plant Sci. 2003, 164, S93-S102. [CrossRef]

3. Kessler, A.; Kalske, A. Plant secondary metabolite diversity and species interactions. Annu. Rev. Ecol. Evol. System. 2018, 49, 115-138. [CrossRef]

4. Duke, S.O.; Pan, Z.; Bajsa-Hirschel, J. Proving the mode of action of phytotoxic phytochemicals. Plants 2020, 9, 1756. [CrossRef]

5. Duke, S.O. Ecophysiological aspects of allelopathy. Planta 2003, 217, 529-539.

6. Dayan, F.E.; Duke, S.O. Natural compounds as next-generation herbicides. Plant Physiol. 2014, 166, 1090-1105. [CrossRef]

7. Graña, E.; Costas-Gil, A.; Longueira, S.; Celeiro, M.; Teijeira, M.; Reigosa, M.J.; Sánchez-Moreiras, A.M. Auxin-like effects of the natural coumarin scopoletin on Arabidopsis cell structure and morphology. J. Plant Physiol. 2017, 218, 45-55. [CrossRef]

8. Bourgaud, F.; Hehn, A.; Larbat, R.; Doerper, S.; Gontier, E.; Kellner, S.; Matern, U. Biosynthesis of coumarins in plants: A major pathway still to be unravelled for cytochrome P450 enzymes. Phytochem. Rev. 2006, 5, 293-308. [CrossRef]

9. Razavi, S.M. Plant Counnarins as Allelopathic Agents. Int. J. Biol. Chem. 2011, 5, 86-90. [CrossRef]

10. Matos, M.J.; Santana, L.; Uriarte, E.; Abreu, O.A.; Molina, E.; Yordi, E.G. Coumarins-An important class of phytochemicals. Phytochem. Isol. Characterisation Role Hum. Health 2015, 25, 533-538. 
11. Costa, T.M.; Tavares, L.B.B.; de Oliveira, D. Fungi as a source of natural coumarins production. Appl. Microbiol. Biotech. 2016, 100, 6571-6584. [CrossRef] [PubMed]

12. Niro, E.; Marzaioli, R.; De Crescenzo, S.; D’Abrosca, B.; Castaldi, S.; Esposito, A.; Fiorentino, A.; Rutigliano, F. Effects of the allelochemical coumarin on plants and soil microbial community. Soil Biol. Biochem. 2016, 95, 30-39. [CrossRef]

13. Robe, K.; Conejero, G.; Gao, F.; Lefebvre-Legendre, L.; Sylvestre-Gonon, E.; Rofidal, V.; Hem, S.; Rouhier, N.; Barberon, M.; Hecker, A. Coumarin accumulation and trafficking in Arabidopsis thaliana: A complex and dynamic process. New Phytol. 2021, 229, 2062-2079. [CrossRef] [PubMed]

14. Clemens, S.; Weber, M. The essential role of coumarin secretion for Fe acquisition from alkaline soil. Plant Signal. Behav. 2016, 11, e1114197. [CrossRef]

15. Tsai, H.H.; Schmidt, W. Mobilization of iron by plant-borne coumarins. Trends Plant Sci. 2017, 22, 538-548. [CrossRef] [PubMed]

16. Robe, K.; Izquierdo, E.; Vignols, F.; Rouached, H.; Dubos, C. The coumarins: Secondary metabolites playing a primary role in plant nutrition and health. Trends Plant Sci. 2020, 26, 248-259. [CrossRef]

17. Lundberg, D.S.; Teixeira, P.J. Root-exuded coumarin shapes the root microbiome. Proc. Natl. Acad. Sci. USA 2018, 115, 5629-5631. [CrossRef]

18. Lupini, A.; Sorgonà, A.; Miller, A.J.; Abenavoli, M.R. Short-term effects of coumarin along the maize primary root axis. Plant Signal. Behav. 2010, 5, 1395-1400. [CrossRef]

19. Abenavoli, M.; Nicolò, A.; Lupini, A.; Oliva, S.; Sorgonà, A. Effects of different allelochemicals on root morphology of Arabidopsis thaliana. Allelopath. J. 2008, 22, 245-252.

20. Neumann, J. An auxin-like action of coumarin. Science 1959, 129, 1675-1676. [CrossRef]

21. Jansson, E.; Svensson, S.-B. Coumarin effects on Glycine max hypocotyl explants. Physiol. Plant 1980, 48, 486-490. [CrossRef]

22. Lupini, A.; Araniti, F.; Sunseri, F.; Abenavoli, M.R. Coumarin interacts with auxin polar transport to modify root system architecture in Arabidopsis thaliana. Plant Growth Regul. 2014, 74, 23-31. [CrossRef]

23. Pop, T.I.; Pamfil, D.; Bellini, C. Auxin control in the formation of adventitious roots. Not. Bot. Horti Agrobot. Cluj Napoca 2011, 39, 307-316. [CrossRef]

24. Potters, G.; Pasternak, T.P.; Guisez, Y.; Palme, K.J.; Jansen, M.A. Stress-induced morphogenic responses: Growing out of trouble? Trends Plant Sci. 2007, 12, 98-105. [CrossRef]

25. Zažímalová, E.; Murphy, A.S.; Yang, H.; Hoyerová, K.; Hošek, P. Auxin transporters—Why so many? Cold Spring Harb. Perspect. Biol. 2010, 2, a001552. [CrossRef] [PubMed]

26. Casimiro, I.; Beeckman, T.; Graham, N.; Bhalerao, R.; Zhang, H.; Casero, P.; Sandberg, G.; Bennett, M.J. Dissecting Arabidopsis lateral root development. Trends Plant Sci. 2003, 8, 165-171. [CrossRef]

27. Singh, S.; Yadav, S.; Singh, A.; Mahima, M.; Singh, A.; Gautam, V.; Sarkar, A.K. Auxin signaling modulates LATERAL ROOT PRIMORDIUM 1 (LRP 1) expression during lateral root development in Arabidopsis. Plant J. 2020, 101, 87-100. [CrossRef] [PubMed]

28. Benková, E.; Michniewicz, M.; Sauer, M.; Teichmann, T.; Seifertová, D.; Jürgens, G.; Friml, J. Local, efflux-dependent auxin gradients as a common module for plant organ formation. Cell 2003, 115, 591-602. [CrossRef]

29. Laskowski, M.; Biller, S.; Stanley, K.; Kajstura, T.; Prusty, R. Expression profiling of auxin-treated Arabidopsis roots: Toward a molecular analysis of lateral root emergence. Plant Cell Physiol. 2006, 47, 788-792. [CrossRef]

30. Dubrovsky, J.G.; Napsucialy-Mendivil, S.; Duclercq, J.; Cheng, Y.; Shishkova, S.; Ivanchenko, M.G.; Friml, J.; Murphy, A.S.; Benková, E. Auxin minimum defines a developmental window for lateral root initiation. New Phytol. 2011, 191, 970-983. [CrossRef]

31. Lehman, T.A.; Smertenko, A.; Sanguinet, K.A. Auxin, microtubules, and vesicle trafficking: Conspirators behind the cell wall. J. Exp. Bot. 2017, 68, 3321-3329. [CrossRef]

32. Kleine-Vehn, J.; Łangowski, Ł.; Wiśniewska, J.; Dhonukshe, P.; Brewer, P.B.; Friml, J. Cellular and molecular requirements for polar PIN targeting and transcytosis in plants. Mol. Plant 2008, 1, 1056-1066. [CrossRef]

33. Na, X.; Hu, Y.; Yue, K.; Lu, H.; Jia, P.; Wang, H.; Wang, X.; Bi, Y. Narciclasine modulates polar auxin transport in Arabidopsis roots. J. Plant Physiol. 2011, 168, 1149-1156. [CrossRef]

34. Hu, Y.; Yang, L.; Na, X.; You, J.; Hu, W.; Liang, X.; Liu, J.; Mao, L.; Wang, X.; Wang, H. Narciclasine inhibits the responses of Arabidopsis roots to auxin. Planta 2012, 236, 597-612. [CrossRef] [PubMed]

35. Graña, E.; Sotelo, T.; Díaz-Tielas, C.; Araniti, F.; Krasuska, U.; Bogatek, R.; Reigosa, M.J.; Sánchez-Moreiras, A.M. Citral induces auxin and ethylene-mediated malformations and arrests cell division in Arabidopsis thaliana roots. J. Chem. Ecol. 2013, 39, $271-282$. [CrossRef] [PubMed]

36. Hu, Y.; Na, X.; Li, J.; Yang, L.; You, J.; Liang, X.; Wang, J.; Peng, L.; Bi, Y. Narciclasine, a potential allelochemical, affects subcellular trafficking of auxin transporter proteins and actin cytoskeleton dynamics in Arabidopsis roots. Planta 2015, 242, 1349-1360. [CrossRef]

37. Araniti, F.; Grana, E.; Krasuska, U.; Bogatek, R.; Reigosa, M.J.; Abenavoli, M.R.; Sanchez-Moreiras, A.M. Loss of gravitropism in farnesene-treated arabidopsis is due to microtubule malformations related to hormonal and ROS unbalance. PLoS ONE 2016, 11, e0160202. [CrossRef] [PubMed]

38. Li, P.; Ding, L.; Zhang, L.; He, J.; Huan, Z. Weisiensin B inhibits primary and lateral root development by interfering with polar auxin transport in Arabidopsis thaliana. Plant Physiol. Biochem. 2019, 139, 738-745. [CrossRef] [PubMed] 
39. López-González, D.; Costas-Gil, A.; Reigosa, M.J.; Araniti, F.; Sánchez-Moreiras, A.M. A natural indole alkaloid, norharmane, affects PIN expression patterns and compromises root growth in Arabidopsis thaliana. Plant Physiol. Biochem. 2020, 151, 378-390. [CrossRef]

40. Araniti, F.; Bruno, L.; Sunseri, F.; Pacenza, M.; Forgione, I.; Bitonti, M.B.; Abenavoli, M.R. The allelochemical farnesene affects Arabidopsis thaliana root meristem altering auxin distribution. Plant Physiol. Biochem. 2017, 121, 14-20. [CrossRef] [PubMed]

41. Chaimovitsh, D.; Abu-Abied, M.; Belausov, E.; Rubin, B.; Dudai, N.; Sadot, E. Microtubules are an intracellular target of the plant terpene citral. Plant J. 2010, 61, 399-408. [CrossRef]

42. Graña, E.; Díaz-Tielas, C.; López-González, D.; Martínez-Peñalver, A.; Reigosa, M.; Sánchez-Moreiras, A. The plant secondary metabolite citral alters water status and prevents seed formation in Arabidopsis thaliana. Plant Biol. 2016, 18, 423-432. [CrossRef]

43. Svensson, S.B. The effect of coumarin on root growth and root histology. Physiol. Plant 1971, 24, 446-470. [CrossRef]

44. Mizukami, Y. A matter of size: Developmental control of organ size in plants. Curr. Opin. Plant Biol. 2001, 4, 533-539. [CrossRef]

45. Ioio, R.D.; Linhares, F.S.; Scacchi, E.; Casamitjana-Martinez, E.; Heidstra, R.; Costantino, P.; Sabatini, S. Cytokinins determine Arabidopsis root-meristem size by controlling cell differentiation. Curr. Biol. 2007, 17, 678-682. [CrossRef] [PubMed]

46. Ioio, R.D.; Nakamura, K.; Moubayidin, L.; Perilli, S.; Taniguchi, M.; Morita, M.T.; Aoyama, T.; Costantino, P.; Sabatini, S. A genetic framework for the control of cell division and differentiation in the root meristem. Science 2008, 322, 1380-1384. [CrossRef]

47. Doerner, P.; Jørgensen, J.-E.; You, R.; Steppuhn, J.; Lamb, C. Control of root growth and development by cyclin expression. Nature 1996, 380, 520-523. [CrossRef]

48. Criqui, M.C.; Parmentier, Y.; Derevier, A.; Shen, W.H.; Dong, A.; Genschik, P. Cell cycle-dependent proteolysis and ectopic overexpression of cyclin B1 in tobacco BY2 cells. Plant J. 2000, 24, 763-773. [CrossRef]

49. Blilou, I.; Xu, J.; Wildwater, M.; Willemsen, V.; Paponov, I.; Friml, J.; Heidstra, R.; Aida, M.; Palme, K.; Scheres, B. The PIN auxin efflux facilitator network controls growth and patterning in Arabidopsis roots. Nature 2005, 433, 39-44. [CrossRef] [PubMed]

50. Abenavoli, M.R.; Sorgonà, A.; Albano, S.; Cacco, G. Coumarin differentially affects the morphology of different root types of maize seedlings. J. Chem. Ecol. 2004, 30, 1871-1883. [CrossRef] [PubMed]

51. Jingyi, W.; Dandan, Y.; Jun, X.; Cai-xia, W.; Guo-qi, Z.; Chen-lan, H. Effect of coumarin on Soughum sudanense seed germination and seedling growth. Pratac. Sci. 2017, 34, 2279-2288.

52. Chen, B.-X.; Peng, Y.-X.; Gao, J.-D.; Zhang, Q.; Liu, Q.-J.; Fu, H.; Liu, J. Coumarin-induced delay of rice seed germination is mediated by suppression of abscisic acid catabolism and reactive oxygen species production. Front. Plant Sci. 2019, 10, 828. [CrossRef] [PubMed]

53. Laplaze, L.; Benkova, E.; Casimiro, I.; Maes, L.; Vanneste, S.; Swarup, R.; Weijers, D.; Calvo, V.; Parizot, B.; Herrera-Rodriguez, M.B. Cytokinins act directly on lateral root founder cells to inhibit root initiation. Plant Cell 2007, 19, 3889-3900. [CrossRef] [PubMed]

54. Bruno, L.; Pacenza, M.; Forgione, I.; Lamerton, L.R.; Greco, M.; Chiappetta, A.; Bitonti, M.B. In Arabidopsis thaliana cadmium impact on the growth of primary root by altering SCR expression and auxin-cytokinin cross-talk. Front. Plant Sci. 2017, 8, 1323. [CrossRef] [PubMed]

55. Na, X.; Hu, Y.; Yue, K.; Lu, H.; Jia, P.; Wang, H.; Wang, X.; Bi, Y. Concentration-dependent effects of narciclasine on cell cycle progression in Arabidopsis root tips. BMC Plant Biol. 2011, 11, 1-13. [CrossRef] [PubMed]

56. Cornman, I. The responses of onion and lily mitosis to coumarin and parasorbic acid. J. Exp. Biol. 1947, 23, 292-297. [CrossRef] [PubMed]

57. Yuksel, B.; Aksoy, O. Cytological effects of coumarin on the mitosis of Lens culinaris Medik. Fresenius Environ. Bull. 2017, 26, 6400-6407.

58. Culligan, K.; Tissier, A.; Britt, A. ATR regulates a G2-phase cell-cycle checkpoint in Arabidopsis thaliana. Plant Cell 2004, 16, 1091-1104. [CrossRef]

59. Wu, S.; Scheible, W.-R.; Schindelasch, D.; Van Den Daele, H.; De Veylder, L.; Baskin, T.I. A conditional mutation in Arabidopsis thaliana separase induces chromosome non-disjunction, aberrant morphogenesis and cyclin B1; 1 stability. Development 2010, 137, 953-961. [CrossRef]

60. De Schutter, K.; Joubès, J.; Cools, T.; Verkest, A.; Corellou, F.; Babiychuk, E.; Van Der Schueren, E.; Beeckman, T.; Kushnir, S.; Inze, D. Arabidopsis WEE1 kinase controls cell cycle arrest in response to activation of the DNA integrity checkpoint. Plant Cell 2007, 19, 211-225. [CrossRef]

61. Hefner, E.; Huefner, N.; Britt, A.B. Tissue-specific regulation of cell-cycle responses to DNA damage in Arabidopsis seedlings. DNA Repair 2006, 5, 102-110. [CrossRef]

62. Weingartner, M.; Criqui, M.-C.; Mészáros, T.; Binarova, P.; Schmit, A.-C.; Helfer, A.; Derevier, A.; Erhardt, M.; Bögre, L.; Genschik, P. Expression of a nondegradable cyclin B1 affects plant development and leads to endomitosis by inhibiting the formation of a phragmoplast. Plant Cell 2004, 16, 643-657. [CrossRef]

63. Serralbo, O.; Pérez-Pérez, J.M.; Heidstra, R.; Scheres, B. Non-cell-autonomous rescue of anaphase-promoting complex function revealed by mosaic analysis of HOBBIT, an Arabidopsis CDC27 homolog. Proc. Natl. Acad. Sci. USA 2006, 103, 13250-13255. [CrossRef]

64. Baskin, T.I.; Wilson, J.E.; Cork, A.; Williamson, R.E. Morphology and microtubule organization in Arabidopsis roots exposed to oryzalin or taxol. Plant Cell Physiol. 1994, 35, 935-942. [PubMed] 
65. Baskin, T.I.; Beemster, G.T.; Judy-March, J.E.; Marga, F. Disorganization of cortical microtubules stimulates tangential expansion and reduces the uniformity of cellulose microfibril alignment among cells in the root of Arabidopsis. Plant Physiol. 2004, 135, 2279-2290. [CrossRef]

66. Fanale, D.; Bronte, G.; Passiglia, F.; Calò, V.; Castiglia, M.; Di Piazza, F.; Barraco, N.; Cangemi, A.; Catarella, M.T.; Insalaco, L. Stabilizing versus destabilizing the microtubules: A double-edge sword for an effective cancer treatment option? Anal. Cell. Pathol. 2015, 2015, 1-19. [CrossRef] [PubMed]

67. Morejohn, L.C.; Fosket, D.E. The biochemistry of compounds with anti-microtubule activity in plant cells. Pharmacol. Ther. 1991, 51, 217-230. [CrossRef]

68. Hugdahl, J.D.; Morejohn, L.C. Rapid and reversible high-affinity binding of the dinitroaniline herbicide oryzalin to tubulin from Zea mays L. Plant Physiol. 1993, 102, 725-740. [CrossRef] [PubMed]

69. Pitts, R.J.; Cernac, A.; Estelle, M. Auxin and ethylene promote root hair elongation in Arabidopsis. Plant J. 1998, 16, 553-560. [CrossRef] [PubMed]

70. Rahman, A.; Hosokawa, S.; Oono, Y.; Amakawa, T.; Goto, N.; Tsurumi, S. Auxin and ethylene response interactions during Arabidopsis root hair development dissected by auxin influx modulators. Plant Physiol. 2002, 130, 1908-1917. [CrossRef]

71. Campanoni, P.; Nick, P. Auxin-dependent cell division and cell elongation. 1-Naphthaleneacetic acid and 2, 4-dichlorophenoxyacetic acid activate different pathways. Plant Physiol. 2005, 137, 939-948. [CrossRef]

72. Li, X.; Gruber, M.Y.; Hegedus, D.D.; Lydiate, D.J.; Gao, M.-J. Effects of a coumarin derivative, 4-methylumbelliferone, on seed germination and seedling establishment in Arabidopsis. J. Chem. Ecol. 2011, 37, 880-890. [CrossRef]

73. Tian, H.; Niu, T.; Yu, Q.; Quan, T.; Ding, Z. Auxin gradient is crucial for the maintenance of root distal stem cell identity in Arabidopsis. Plant Sign. Behav. 2013, 8, e26429. [CrossRef]

74. Goren, R.; Tomer, E. Effects of seselin and coumarin on growth, indoleacetic acid oxidase, and peroxidase, with special reference to cucumber (Cucumis sativa L.) radicles. Plant Physiol. 1971, 47, 312-316. [CrossRef] [PubMed]

75. Andreae, W. Effect of scopoletin on indoleacetic acid metabolism. Nature 1952, 170, 83-84. [CrossRef]

76. Casimiro, I.; Marchant, A.; Bhalerao, R.P.; Beeckman, T.; Dhooge, S.; Swarup, R.; Graham, N.; Inzé, D.; Sandberg, G.; Casero, P.J. Auxin transport promotes Arabidopsis lateral root initiation. Plant Cell 2001, 13, 843-852. [CrossRef] [PubMed]

77. De Rybel, B.; Audenaert, D.; Xuan, W.; Overvoorde, P.; Strader, L.C.; Kepinski, S.; Hoye, R.; Brisbois, R.; Parizot, B.; Vanneste, S. A role for the root cap in root branching revealed by the non-auxin probe naxillin. Nat. Chem. Biol. 2012, 8, 798-805. [CrossRef] [PubMed]

78. Himanen, K.; Boucheron, E.; Vanneste, S.; de Almeida Engler, J.; Inzé, D.; Beeckman, T. Auxin-mediated cell cycle activation during early lateral root initiation. Plant Cell 2002, 14, 2339-2351. [CrossRef]

79. Vanneste, S.; De Rybel, B.; Beemster, G.T.; Ljung, K.; De Smet, I.; Van Isterdael, G.; Naudts, M.; Iida, R.; Gruissem, W.; Tasaka, M. Cell cycle progression in the pericycle is not sufficient for SOLITARY ROOT/IAA14-mediated lateral root initiation in Arabidopsis thaliana. Plant Cell 2005, 17, 3035-3050. [CrossRef]

80. Zhang, Y.; He, P.; Ma, X.; Yang, Z.; Pang, C.; Yu, J.; Wang, G.; Friml, J.; Xiao, G. Auxin-mediated statolith production for root gravitropism. New Phytol. 2019, 224, 761-774. [CrossRef]

81. Dubrovsky, J.G.; Sauer, M.; Napsucialy-Mendivil, S.; Ivanchenko, M.G.; Friml, J.; Shishkova, S.; Celenza, J.; Benková, E. Auxin acts as a local morphogenetic trigger to specify lateral root founder cells. Proc. Nat. Acad. Sci. USA 2008, 105, 8790-8794. [CrossRef] [PubMed]

82. Alarcón, M.; Salguero, J.; Lloret, P.G. Auxin modulated initiation of lateral roots is linked to pericycle cell length in maize. Front. Plant Sci. 2019, 10, 11. [CrossRef] [PubMed]

83. Laskowski, M.J.; Williams, M.E.; Nusbaum, H.C.; Sussex, I.M. Formation of lateral root meristems is a two-stage process. Development 1995, 121, 3303-3310. [CrossRef] [PubMed]

84. Ottenschläger, I.; Wolff, P.; Wolverton, C.; Bhalerao, R.P.; Sandberg, G.; Ishikawa, H.; Evans, M.; Palme, K. Gravity-regulated differential auxin transport from columella to lateral root cap cells. Proc. Natl. Acad. Sci. USA 2003, 100, 2987-2991. [CrossRef] [PubMed]

85. Moreno-Romero, J.; Carme Espunya, M.; Platara, M.; Ariño, J.; Carmen Martínez, M. A role for protein kinase CK2 in plant development: Evidence obtained using a dominant-negative mutant. Plant J. 2008, 55, 118-130. [CrossRef] [PubMed]

86. González-García, M.-P.; Vilarrasa-Blasi, J.; Zhiponova, M.; Divol, F.; Mora-García, S.; Russinova, E.; Caño-Delgado, A.I. Brassinosteroids control meristem size by promoting cell cycle progression in Arabidopsis roots. Development 2011, 138, 849-859. [CrossRef] [PubMed]

87. Holzinger, A.; Kawamura, E.; Wasteneys, G.O. Strategies for imaging microtubules in plant cells. In Cytoskeleton Methods and Protocols; Springer: Berlin/Heidelberg, Germany, 2009; pp. 243-262.

88. Cools, T.; Iantcheva, A.; Maes, S.; Van den Daele, H.; De Veylder, L. A replication stress-induced synchronization method for Arabidopsis thaliana root meristems. Plant J. 2010, 64, 705-714. [CrossRef]

89. Rawlinson, C.; Kamphuis, L.G.; Gummer, J.P.; Singh, K.B.; Trengove, R.D. A rapid method for profiling of volatile and semi-volatile phytohormones using methyl chloroformate derivatisation and GC-MS. Metabolomics 2015, 11, 1922-1933. [CrossRef] 